\author{
Julia Budka
}

\title{
KUSHITE TOMB GROUPS IN LATE PERIOD THEBES ${ }^{1}$
}

\section{INTRODUCTION}

Within the seventy years of Kushite rule in Egypt (Twenty-fifth Dynasty, 722-655 BC) a large number of people must have migrated into Egypt from the south: accompanying the king, working for the court, as soldiers or as traders. Many probably settled in Egypt, either with their families or establishing new families by marriage with Egyptian women (Morkot 2000: 289). One can assume a large number of "second generation Kushites born in Egypt” (Morkot 2000: 289) and not all of them had to leave their new homeland with the retreat of the Kushite rulers.

Thebes was a prosperous city during the Twenty-fifth Dynasty with a notable Kushite presence and royal building activity (Redford 2004: 117-138). Certain key offices, like the post of mayor of Thebes, were held by Kushites who were selected and appointed by the king. ${ }^{2}$ King's sons were installed as High Priests, as well as in other offices, and marriage alliances with leading Theban families are well attested, e.g. Monthouemhat (Morkot 2000: 237). Despite these factors, evidence for Kushites in Egypt is scarce, especially outside the royal family branch. The main reason is not missing evidence, but the problem of identifying Kushites in the Egyptian context (Wenig 1990: 346 and Vittmann 2007). Leading officials of Kushite descent in particular may have adopted Egyptian names and were represented in Egyptian style (cf. Horemakhet and Horakhbit and other royal sons). Nevertheless, there are several ways to clarify the Kushite origin of a person buried in Late Period Egypt: especially helpful are his/her name or the names of the parents and characteristic physical proportions, coiffure and costume as shown on coffins, stelae and other objects.

Important evidence for Kushites in rather lower official positions comes from tomb VII in the Austrian concession in the Asasif. Apart from the contents of this small funerary monument, remarkably few tomb groups of Kushite families in Egypt have survived. ${ }^{3}$ This paper gives an overview of the tomb groups found in Thebes.

\section{Tomb Architecture}

Several Late Period burials of different types at Western Thebes are associated with people of Kushite origin [Fig. 1]. The earliest evidence comes from intrusive shaft burials in Sheikh Abd el-Gurna (TT 99 and TT 367). This type of architecture - a shaft sunk in an earlier structure - is typical of the Third Intermediate Period (Strudwick 2000: 252 and Budka 2006b: II, 584).

Around $700 \mathrm{BC}$ a new type of tomb was developed at Thebes. This was the so-called tomb palace (Grabpalast), a monumental tomb with a freestanding superstructure in mud brick. The earliest was built by Harwa in the Northern Asasif (TT 37) (Eigner 1984: 37-40). Of special interest are the more or less contemporaneous structures further south. Two monumental tombs in the area known as the Southern Asasif can be assigned to Kushites: the tomb of Karabesken (TT 391), mayor of Thebes and Fourth prophet of Amun, and that of the $k$-priest Karakhamun (TT 223) (Eigner 1984: 34, Fig. 8; Budka 2006b: I, 78-80). The dating of Karabesken is currently being discussed, but he seems to have been the predecessor of Monthuemhat (TT 34). ${ }^{4}$ The origins of the owners of two more tombs in this

1 This study is part of my PhD thesis on the Austrian excavations in the Asasif, supervised by Manfred Bietak and Helmut Satzinger (Budka 2006b: vol. III, 566-603; Budka in press: 330-352). I have benefited considerably from communication with Günter Vittmann and the use of his then unpublished paper (now Vittmann 2007), especially on the subject of Kushite personal names and orthographies. I am indebted to Nigel Strudwick for information on the burials in TT 99.

2 Strudwick 1995: 93 describes this policy as "Nubian kings placing their own men in power at Thebes".

3 Royal women and some of their courtiers were buried in Abydos; see Priese 1968: 178-179; Leahy 1994; Lohwasser 2001: 79-80.

${ }^{4}$ Leclant 1961: 270, note 8; Leclant 1965: 389. For the differing dates for Karabesken, see Kitchen, 1996: 482 and $\$ 344$ (first half of Twenty-fifth Dynasty) and Strudwick 1995: 93, note 111 (later, within the second half, following Taylor; see also Payraudeau 2003: 147, note 89). I am inclined to prefer the earlier date and thus follow Eigner 1984 in his classification of Karabesken's funerary monument as the early type. 
Southern group - TT 390, Iritieru and TT 132, Ramose - are unclear; a Kushite connection cannot be ruled out.

These tombs in the Southern Asasif are important for the development of the Late Period Grabpalast-type with its freestanding monumental superstructure. Eigner calls their axial orientation typically Kushite (Eigner 1984: 43 and Budka 2006b: I, 78-79). Another characteristic of the southern group is the use of a stairway to reach the substructures. This feature may well be of Nubian inspiration: stairways were elements of Kushite tombs beginning in the reign of Piye (747-722) and thus earlier than the Egyptian examples. ${ }^{5}$ The first to abandon axial orientation for his tomb was Monthuemhat whose tomb (TT 34 ) is situated in the Northern Asasif. Thereafter, this area became the most important part of the Theban Necropolis during the Late Period.
A series of small tombs with mud-brick superstructures was built in the Northern Asasif against the prominent feature designated as Hill 104. These structures can be dated between 750$650 \mathrm{BC}$ and are earlier than similar ones on the plain in the eastern part of the Asasif. ${ }^{6}$ Since tomb VII of the Austrian concession can be attributed to a family of Kushite origin (Irw and Kherirw), it is tempting to assume a cluster of Kushite burials along Hill 104. Interestingly, the small tomb VII shows many characteristics of a monumental Grabpalast on a smaller scale, including a stairway leading to the substructure.

\subsection{TT 99: intrusive shaft burials}

During excavations of the New Kingdom tomb of Sennefer (TT 99), conducted by the University of Cambridge under the directorship of Nigel Strudwick, several intrusive shafts were cleared.

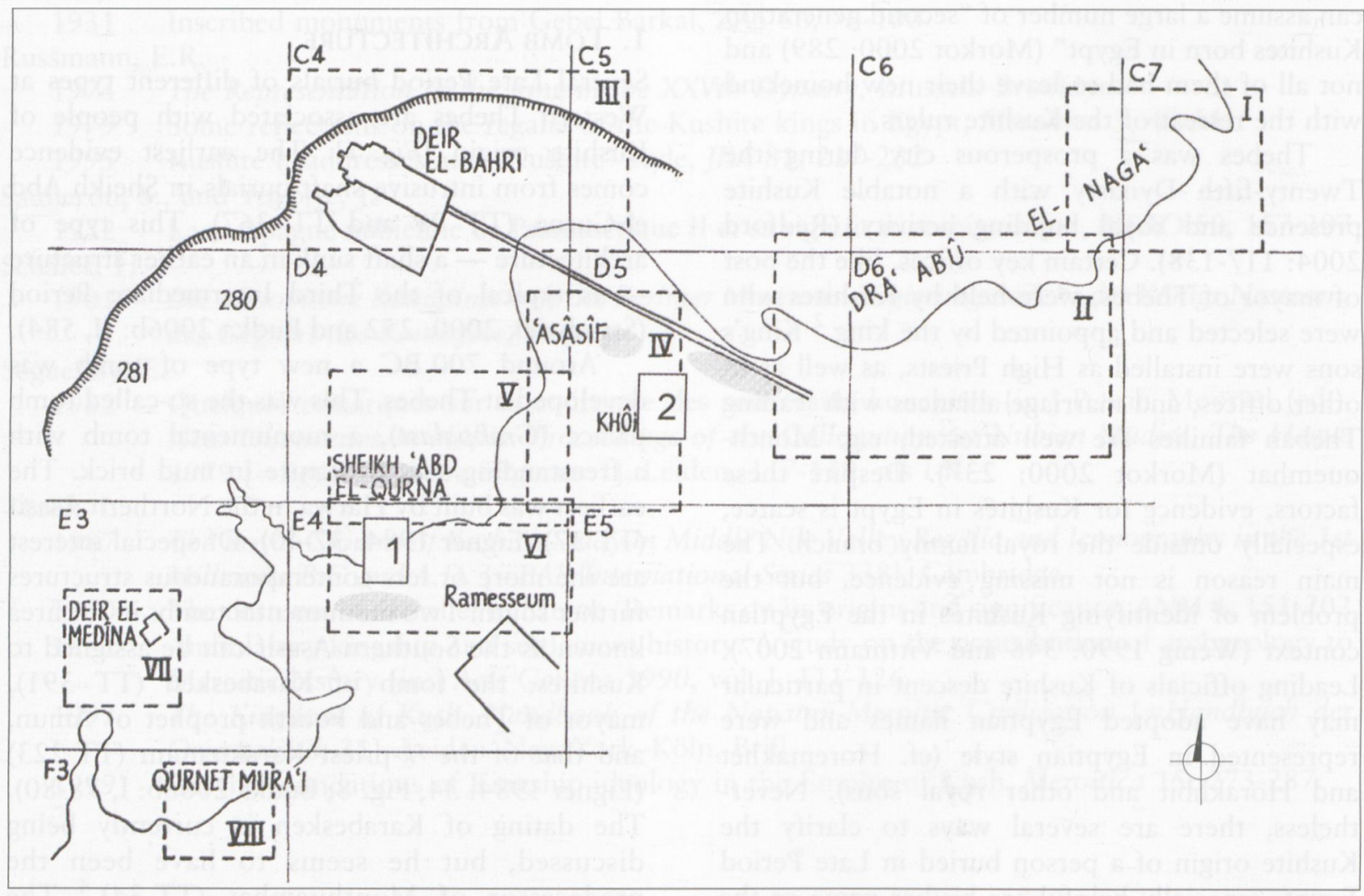

Fig. 1. Sketch map of Western Thebes with locations of Kushite burials (after PM I, 1/2). 1 - Southern Asasif and Sheikh Abd el-Gurna group (TT 99 and TT 367); 2 - Northern Asasif (Hill 104 and TT 33)

${ }^{5}$ Cf. Dunham 1950: 2-3, Ku. 17 and Dunham 1955: Nu. 1, Nu. 35, Nu. 36. Current research on stairway tombs and other monuments in Sanam, conducted by Angelika Lohwasser, raises the possibility that there could be stairways earlier than Piye (Lohwasser, personal communication, August 2006).

6 The earliest tombs of the Third Intermediate Period in the Asasif are probably situated further to the west, around the tomb of Harwa, since traces of mud-brick architecture were found in the vicinity of TT 196 and dated to the Third Intermediate Period, see Graefe 1990: 37-38; 2003: 8 and 30. The situation around the Middle Kingdom tomb of Intef (see Arnold and Settgast 1973: 184) is similar, suggesting a nucleus of the Third Intermediate Period necropolis nearby within the Asasif, cf. Budka 2006b: I, 102.

7 Strudwick 1995: 91-94 and http://www.newton.cam.ac.uk/egypt/tt99/reuse.html (28.12.2006) for information on the phase of re-use during the Twenty-fifth Dynasty. 
Shafts A and B yielded material which is clearly associated with Kushites. Several of the mummy bandages discovered bore the name of Shabako and the names and titles of the Fourth Priest of Amun Wedjahor and of his son, the Fourth Priest of Amun Horenpe. Since the linen shrouds give year dates as well, these officials can be securely dated (see Strudwick 2000) [see Table 1]. Another important discovery was the openwork coffin case of Niw, daughter of Padiamun, Priest of Amun in Gempaaton (Kawa). This is an unequivocal link to Nubia. The connection is underscored by the representation of Niw on her coffin: she wears an Egyptian garment but her hair is cut very short to resemble the typical coiffure of Kushite women. ${ }^{8}$ The mud shabtis from TT 99 provide further evidence for the Kushite origin of the persons buried there. Unlike Egyptian examples, these figures carry baskets on their heads. The only parallels found come from the burials of royal women in the cemetery at Kurru. ${ }^{9}$ For this reason it is tempting to attribute the shabtis from TT 99 to Niw.

\subsection{Tomb VII: intact burials in a tomb with mud-brick superstructure}

In 1971, an Austrian team directed by Manfred Bietak working in the debris on the slope of Hill 104 uncovered a small tomb, later registered as tomb VII [Fig. 2] (Bietak 1972: 30-35; Budka 2006b: I, 160-201 and Budka in press: 111-132). The relatively complete equipment of several burials came to light in burial chambers 2 and 3,

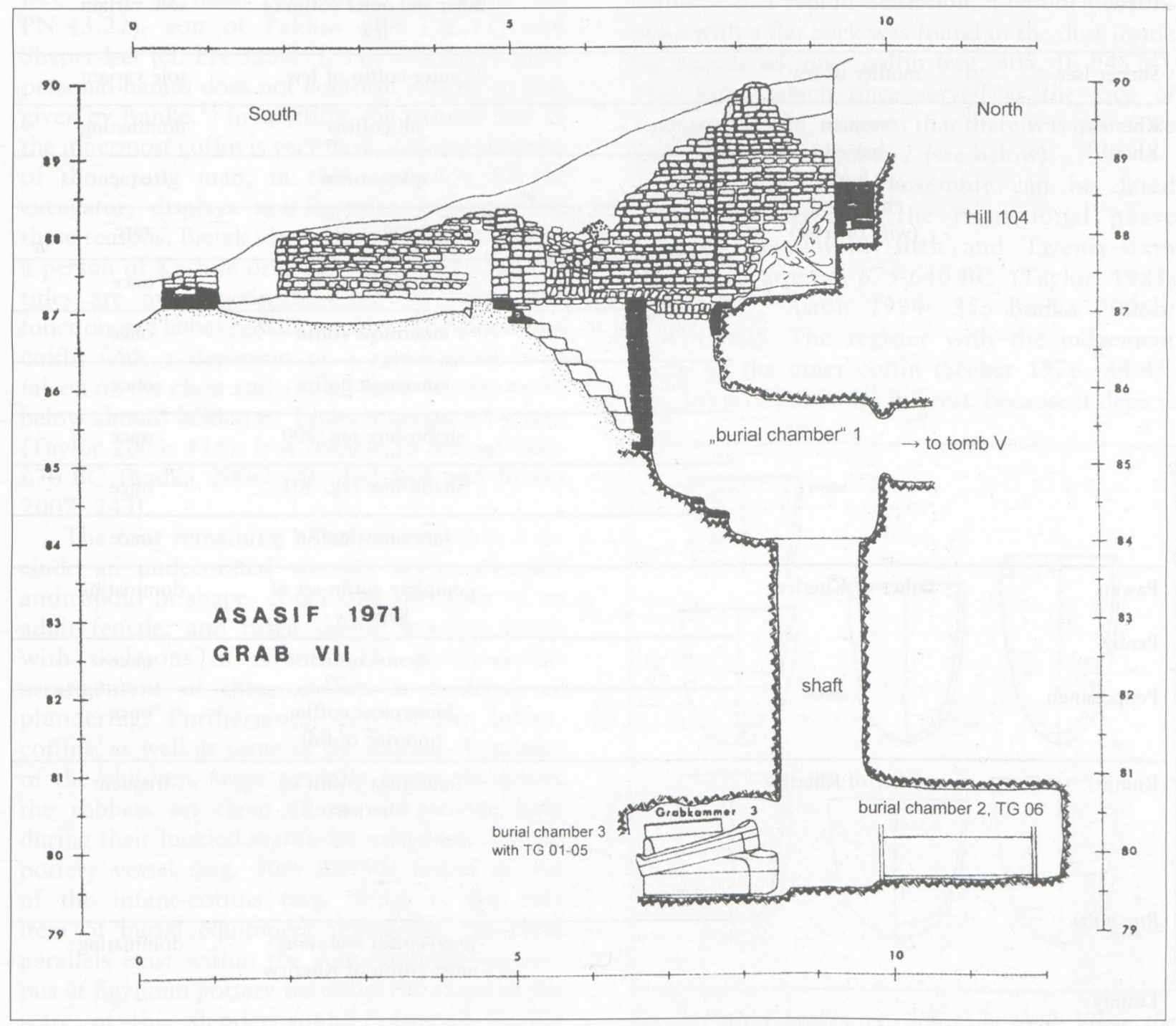

Fig. 2. Tomb VII in the Austrian concession at the Asasif (section, after Bietak 1972)

${ }^{8}$ Strudwick 2000: 254; for pictures, see http://www.newton.cam.ac.uk/egypt/tt99/ (25.08.2006).

9 See Dunham 1950: Pl. XLVI, D. Ku. 62. 19-4-146, E. Ku. 71. 19-4-201, Pl. XLVII, A. Ku. 72. 19-4-202 and Strudwick 2000. As a parallel for this peculiar type Schneider 1977: 172 refers to Dunham 1955: Fig. 199, an illustration based on the previously cited finds from Kurru, not on pieces found in Nuri. 
providing the first concrete information about the ownership and date of one of the tombs set into the hillside.

The mud-brick superstructure of tomb VII, erected between two pre-existing structures (tomb V and tomb XXIV), is divided into two parts: a small open court at the front and a vaulted cult sanctuary with a niche at the back. A staircase opening in the courtyard provides access to the substructure [cf. Fig. 2]. ${ }^{10}$ The six steps comprising it are built of reused blocks from the causeway of Thutmosis III. At the foot of the last step the

Table 1. Variant writings of the names of Kushites as attested in Tomb VII

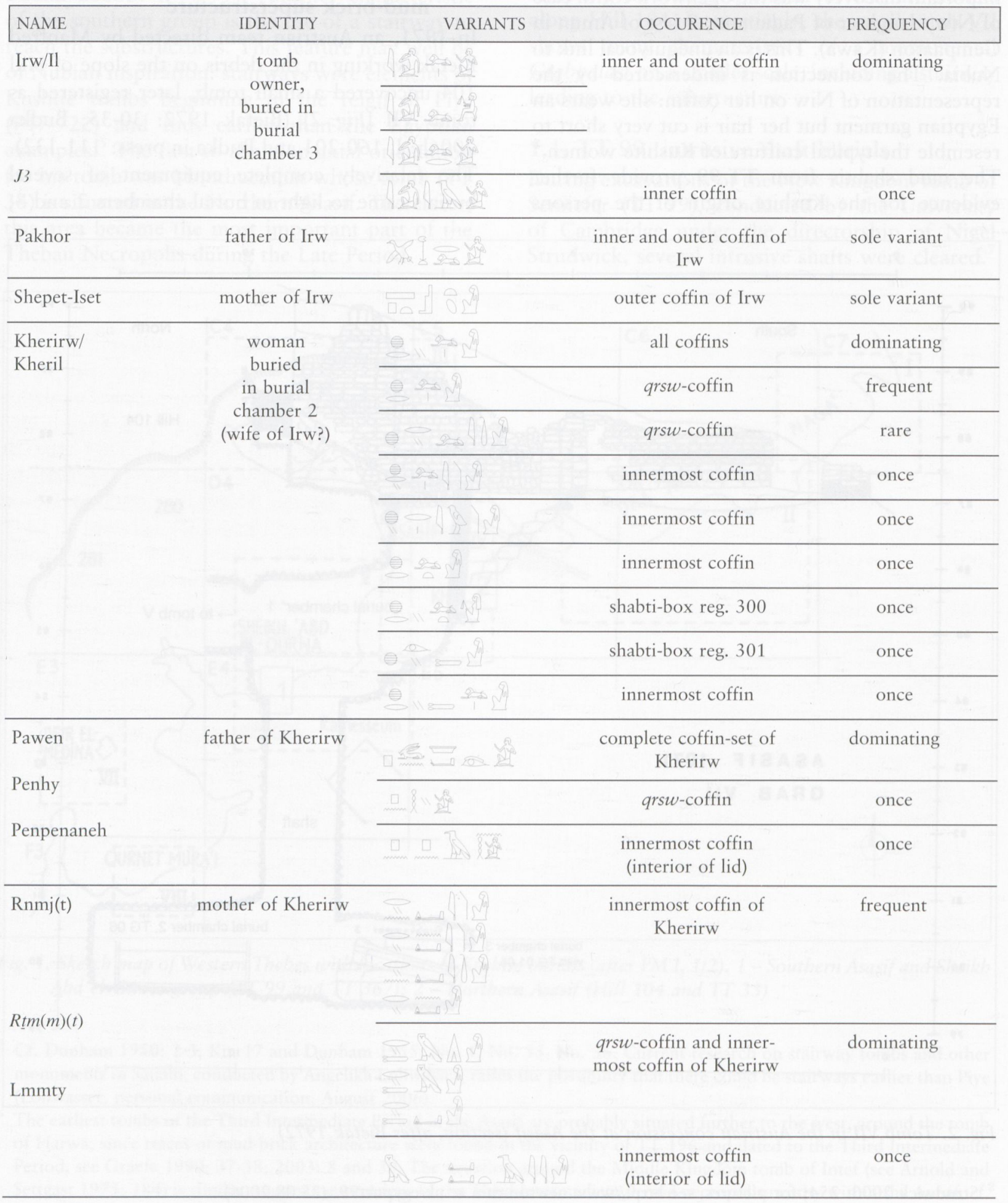

10 The "Grab mit Felsräumen und vorgesetztem Schlammziegelbau" type according to Eigner 1984: 36. 
excavators found an intact wall built of mudbrick. Behind it a corridor opens into a small chamber. In a later building phase, this room was used as a burial chamber ("burial chamber" 1 in Fig. 2). In the floor of this chamber a shaft, $3 \mathrm{~m}$ long, descends to the original burial chambers.

Burial chamber 3 belongs to the first building phase. When discovered it was full of rubble and stones. In this debris, five wooden coffins were found together in a heap. At the very bottom of the pile, a sparsely decorated anthropoid coffin came to light; inside it there was another wooden case with rich decoration. The inner coffin disclosed the untouched burial of an adult male, covered with a fine bead net and provided with amulets. The body itself was poorly preserved (Bietak 1972: 34, Pls 23-25). The inscriptions [see Table 1] name the owner as Irw/Il (cf. PN 43.22), son of Pakhor (PN 116.17) and Shepet-Iset (cf. PN 325.17). The writing of these personal names does not conform exactly to that given by Ranke. ${ }^{11}$ In addition, the painted face of the innermost coffin is very dark, and the skeleton of the young man, in the estimation of the excavator, displays non-Egyptian features. For these reasons, Bietak identifies the tomb owner as a person of Kushite origin (Bietak 1972: 34). No titles are mentioned; therefore his status and function in Thebes remain unclear. The innermost coffin with a depiction of a ram-headed solar falcon on the chest and a small scale Abydos fetish below should belong to Taylor's design $4 A$ group (Taylor 2003: 115). It is datable to around 700670 BC (Budka 2006b: II, 462-468 and Budka 2007: 243).

The four remaining burials in chamber 3 include an undecorated wooden coffin, roughly anthropoid in shape, containing the body of an adult female, and three simple wooden boxes with skeletons of infants. The helter-skelter arrangement of these coffins is evidence of plundering. Furthermore, two of the infantcoffins, as well as some of the mummy bandages of the children, were partially burnt. Evidently the robbers set them aflame to provide light during their hurried search for valuables. A small pottery vessel (reg. 306, A1998) found in one of the infant-coffins (reg. 305c) is the only item of burial equipment remaining. No close parallels exist within the contemporaneous corpus of Egyptain pottery for either the shape or the ware of this slender round-bottomed beaker [Fig. 3] (Budka 2006b: III, 589 and Budka 2007: 244).
Burial chamber 2 also belongs to the first building phase of tomb VII, but it is probably slightly later in date than chamber 3 . Even though the chamber suffered intense plundering and the mummy is missing, the nearly complete set of burial equipment of a lady named Kherirw was found [Fig. 4]. ${ }^{12}$ The tomb group comprises a set of coffins (a large outer qrsw-coffin still in situ, an anthropoid intermediary coffin and an inner case of anthropoid shape with a pedestal), a bead net (fragments found within the innermost case), two shabti-boxes full of mud shabtis (196 and 181, in total 377 pieces) and an uninscribed wooden Osiris statuette. The wooden figure of a jackal, found in the fill of the shaft just outside chamber 2, is like those customarily attached to the lids of qrsw-coffins; it might derive from Kherirw's coffin of that type. In addition, a wooden coffinmask with a flat back was found in the dust inside the plundered inner coffin (reg. 305, JE 94514). This item, which once served as the face of a separate coffin, suggests that there was one more burial made in chamber 2 (see below).

Kherirw's coffin ensemble can be dated stylistically towards the transitional phase between the Twenty-fifth and Twenty-sixth Dynasties, around 675-640 BC (Taylor 1985: II, 365-367; Aston 1994: 35; Budka 2006b: II, 474-482). The register with the judgement scene on the inner coffin (Seeber 1976: 44-45, cat. 36) is of particular interest, because it depicts

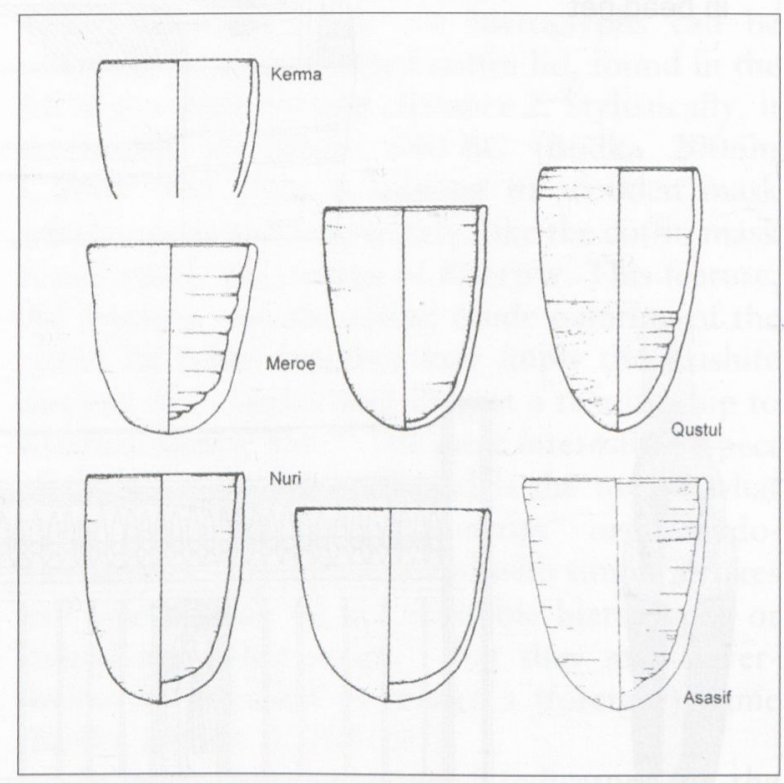

Fig. 3. Pottery beaker reg. 306 from tomb VII in the Asasif and comparable pieces from the Sudan (not to scale).

11 Morkot 2000: 250 compared the name Iru and its spelling with that of Alara.

12 Her relationship with Iru remains dubious in some aspects, but marriage between the two is likely; see in more detail Budka 2006b: I, 197-201. 


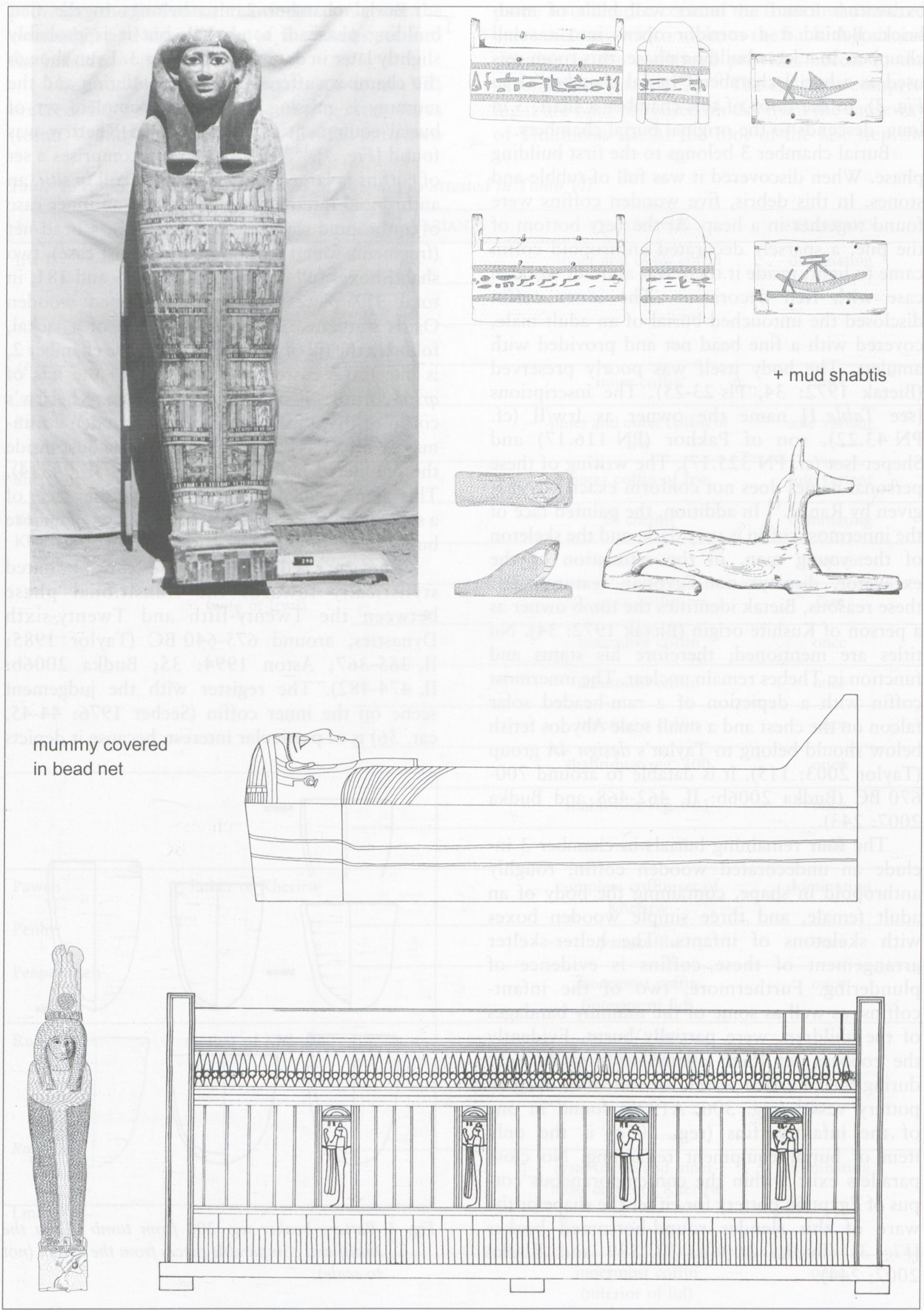

Fig. 4. Tomb group of Kheriww: set of coffins, Osiris statuette, 2 shabti-boxes + shabtis, wooden jackal and falcon(s) as possible accessories of qrsw-coffin; (not to scale). 
the deceased (as on the lid of the qrsw-coffin) with non-Egyptian physique and costume. Both are clearly identifiable as Kushite in character. ${ }^{13}$ The lady Kherirw, daughter of Pawen and Lmmty, has a non-Egyptian coiffure (short wig or more likely natural, very curly hair) and wears a Kushite

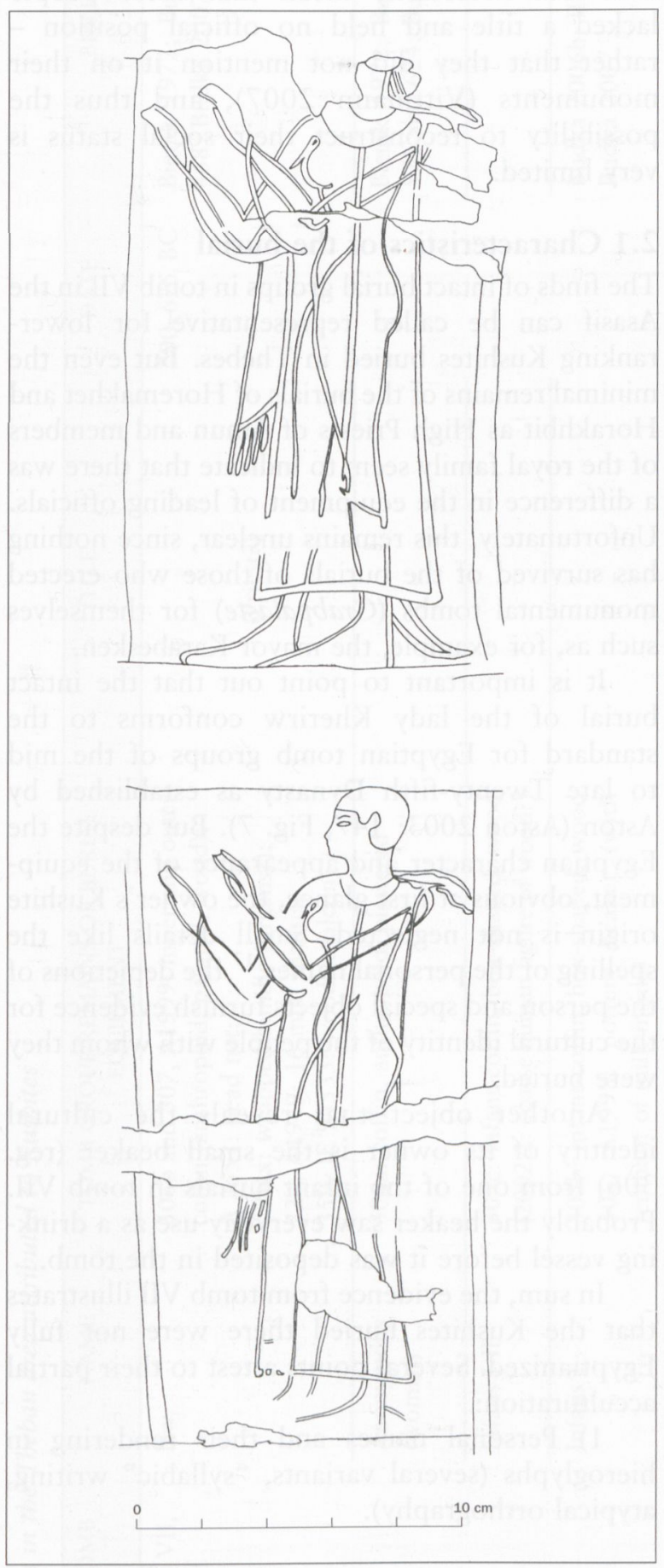

Fig. 5. Representations of Kherirw in Kushite costume on her qrsw-coffin (scale 1:2). garment with fringed sleeves [Fig. 5]. Another characteristically Kushite feature of this costume is a small tail-like tassel at the hem which, according to Lohwasser, is a female fertility amulet in the shape of a fox-tail (Lohwasser 1999: 593).

The personal names in the inscriptions on the coffins support the identification of the woman as Kushite [Table 1]. On Kherirw's coffins, her name occurs with varying orthography, just as in the case of Irw (Budka 2006b: I, 193, Table 14; Budka 2007: 246-247; Budka and Kammerzell 2007: 171). There is a noticeable difference between the writing used on the qrsw-coffin, the intermediary and the inner coffin, and also between the exterior of the latter and the underside of its lid. On the last, the father's name in a syllabic writing is clearly not Egyptian, but rather the orthography may be termed "Kushite" (Penpen-aneh/Penah, instead of Pawen, see Table 1). Also the mother's name, Lmmty, appears in several variants and possibly illustrates difficulties in spelling a foreign name (Budka and Kammerzell 2007: 171; cf. Zibelius-Chen 2009: 105-107 for a possible relation between this name and the Meroitic personal name It-ye).

The set of coffins and the two shabti-boxes are the only objects of Kherirw's equipment that were inscribed. The front of her Osiris statuette, where the personal name of the owner is regularly written, was painted yellow without a trace of any script (Budka 2003: 35-36; Budka 2006b: II, 420421). A similar "lack" of hieroglyphs can be observed on a fragmented coffin lid, found in the fill of the shaft outside chamber 2. Stylistically, it is datable to before $640 \mathrm{BC}$ (Budka 2006b: I, 200). The piece is missing its wooden mask which was worked separately, like the coffin mask found inside the coffins of Kherirw. This feature, the findspot and the rather crude painting of the coffin lid taken together may imply the Kushite descent of its owner and suggest a relationship to Kherirw and/or Irw. ${ }^{14}$ The most interesting aspect of the texts on the coffin lid is the use of what could be called a "pseudo-script" or "pseudohieroglyphs": the columns end with simple strokes and lines, which do not resemble hieroglyphs or indeed any other script, ${ }^{15}$ but they may nevertheless be intended to render a (foreign?) name (Budka 2006b: II, 200-201).

In sum, there are several indicators for the non-Egyptian identity of the persons buried in tomb VII. Of particular importance are the coffin

13 Of the few representations showing private individuals of Kushite descent wearing traditional costumes, those of Kherirw are the only ones to survive on coffins until now.

14 For details of possible relationships, see Budka 2006b: I, 172, 200-201.

15 Hieratic or demotic can be ruled out; for verifying this assumption I am indebted to Günter Vittmann. 
ensembles of both Irw and Kherirw with their inscriptions, variants in personal names and figures depicted in Kushite costume. A further, very clear indication of foreign origin is the beaker found within the infant-coffin in burial chamber 3. It is made of a non-Egyptian marl fabric which has its closest parallels in vessels from the chapel of Amenirdis in Medinet Habu and particularly in the Kushite cemeteries (e.g. Nuri, see Fig. 3). Because the beaker was deposited with one of the infants, it is reasonable to assume that these children belong to Irw's family and were buried during the Twenty-fifth Dynasty.

The salient aspect of the burials of both Irw and Kherirw is what may be termed a dualistic approach (Budka 2007: 249-250). Although the type of tomb, the coffins and the choice of equipment (except for the Kushite beaker) are entirely Egyptian, an indigenous touch was added to everything, from the texts - the (mis)spelling of the names - to the representations (costume and coiffure of the figures).

\section{Kushite Tomb Groups IN Thebes}

No objects of the original equipment have survived from the burials in the monumental Kushite tombs in the Southern Asasif. The case of Wedjarenes, one of Monthuemhat's wives and a granddaughter of Piye, is somewhat exceptional. A small number of shabtis attest to her burial in Egypt - she was probably interred with her husband in the Northern Asasif in TT 34 (Lohwasser 2001: 190-191 with literature). Aside from this single exception, evidence for Kushite burials is limited to intrusive shaft burials, comprising tomb groups of high-ranking families allied by marriage with Kushites, like Wedjahor and Niw, ${ }^{16}$ as well as simple priests of Kushite descent, like Ididi and his family, and to small buildings with mud-brick superstructure like tomb VII in the Asasif which yielded the remains of a Kushite family of presumably even lower rank, since no titles are mentioned.

In all, 20 tomb groups (TG 1-20) in the Theban area can be attributed to Kushites [Table 2]. Seven of these burials come from the small tomb VII; therefore the current state of evidence is very selective - there must have been many more burials in Thebes (Wenig 1990: 346).
As Table 2 illustrates, most of the owners of known tomb groups held either priestly office or title, or no title at all. Vittmann has shown that the lack of titles is a phenomenon very well attested for foreigners in Egypt during the first millennium (Vittmann 1978: 101 and 2007). It does not necessarily mean that these people lacked a title and held no official position rather that they did not mention it on their monuments (Vittmann 2007), and thus the possibility to reconstruct their social status is very limited.

\subsection{Characteristics of the burial}

The finds of intact burial groups in tomb VII in the Asasif can be called representative for lowerranking Kushites buried in Thebes. But even the minimal remains of the burials of Horemakhet and Horakhbit as High Priests of Amun and members of the royal family seem to indicate that there was a difference in the equipment of leading officials. Unfortunately, this remains unclear, since nothing has survived of the burials of those who erected monumental tombs (Grabpaläste) for themselves such as, for example, the mayor Karabesken.

It is important to point out that the intact burial of the lady Kherirw conforms to the standard for Egyptian tomb groups of the mid to late Twenty-fifth Dynasty as established by Aston (Aston 2003: 147, Fig. 7). But despite the Egyptian character and appearance of the equipment, obvious at first glance, the owner's Kushite origin is not neglected. Small details like the spelling of the personal names, ${ }^{17}$ the depictions of the person and special objects furnish evidence for the cultural identity of the people with whom they were buried.

Another object that reveals the cultural identity of its owner is the small beaker (reg. 306) from one of the infant burials in tomb VII. Probably the beaker saw everyday use as a drinking vessel before it was deposited in the tomb.

In sum, the evidence from tomb VII illustrates that the Kushites buried there were not fully Egyptianized. Several points attest to their partial acculturation:

1) Personal names and their rendering in hieroglyphs (several variants, "syllabic" writing, atypical orthography).

16 Wedjahor may have been married to Niw (cf. Vittmann 2007 and Nigel Strudwick, personal communication). Unlike the case of Niw, a Kushite origin of Wedjahor and Horenpe is not certain, but I believe very likely. Their Egyptian names and appearance are probably due to their positions as high-ranking officials (cf. Wenig 1990: 346). If the assumption of a marriage between Wedjahor and Niw proves to be correct, this would make Horenpe at least half-Kushite.

17 The large number of varying writings for the personal names as found on coffins and shabti-boxes (cf. Table 1) may be indicative of the limited or missing ability of the owners/purchasers to write and read, but on the other hand, it could also document the efforts of Egyptian scribes/craftsmen to write names that sounded very unfamiliar to their ears and were not Egyptian (cf. above, case of Lmmty). 


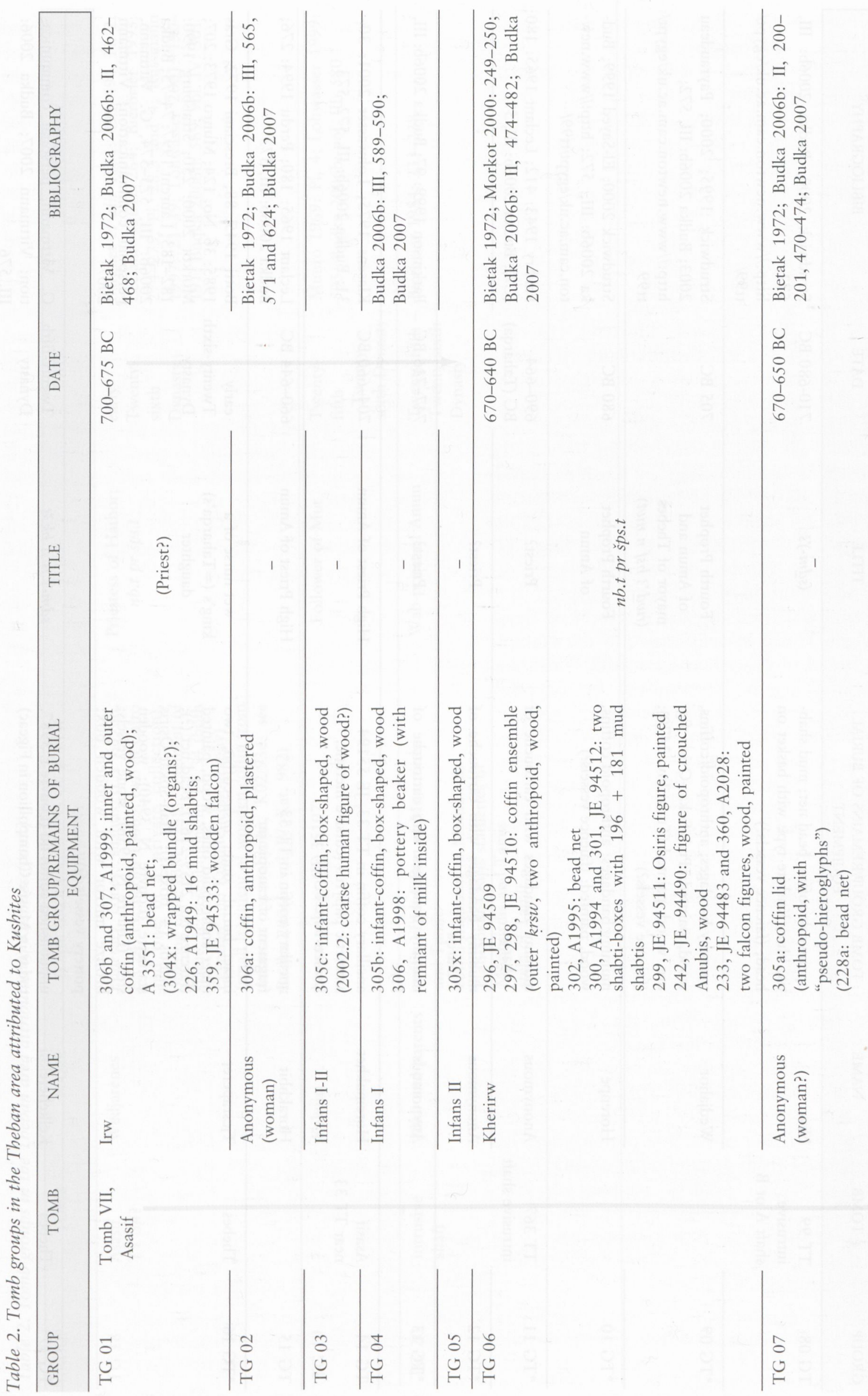




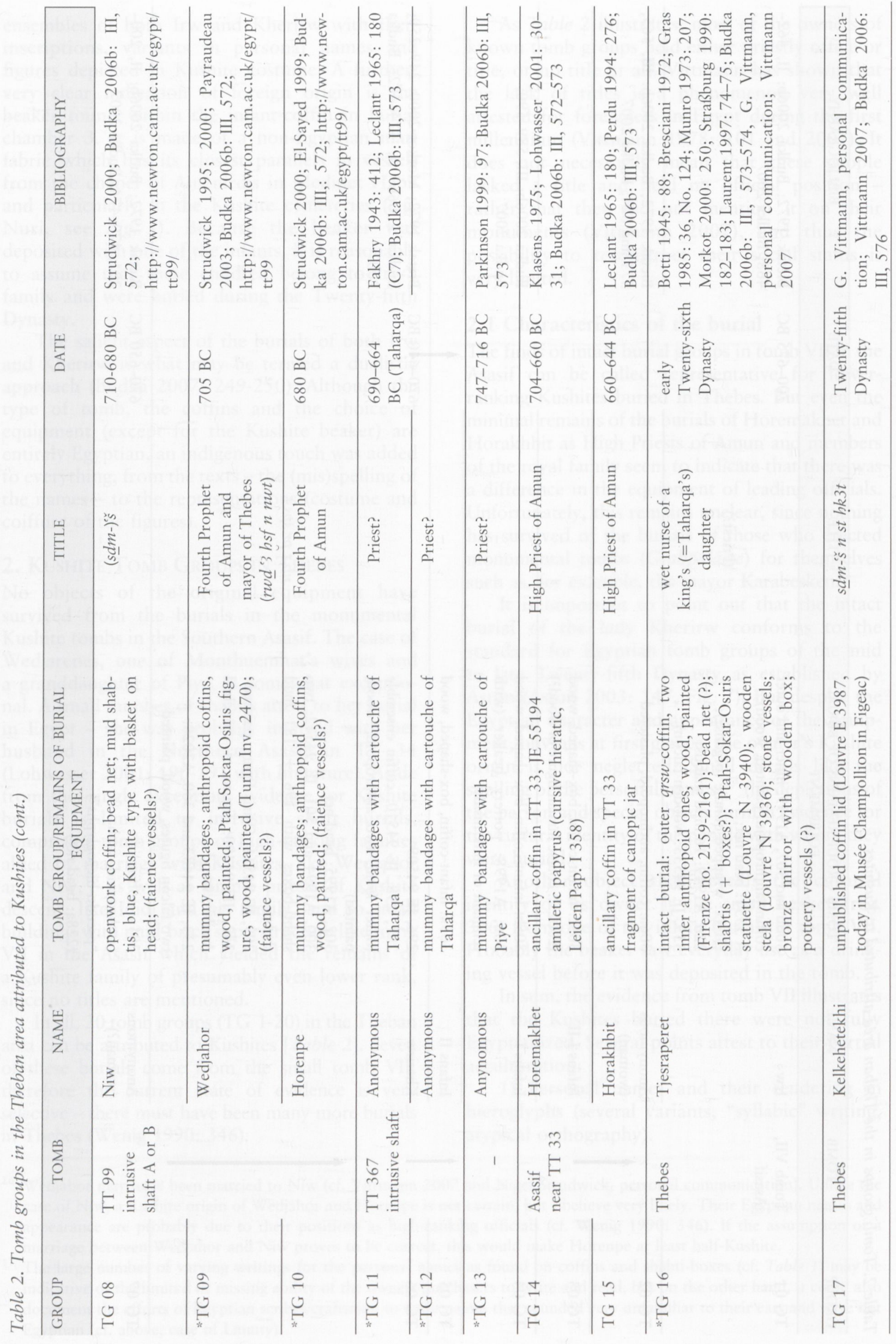




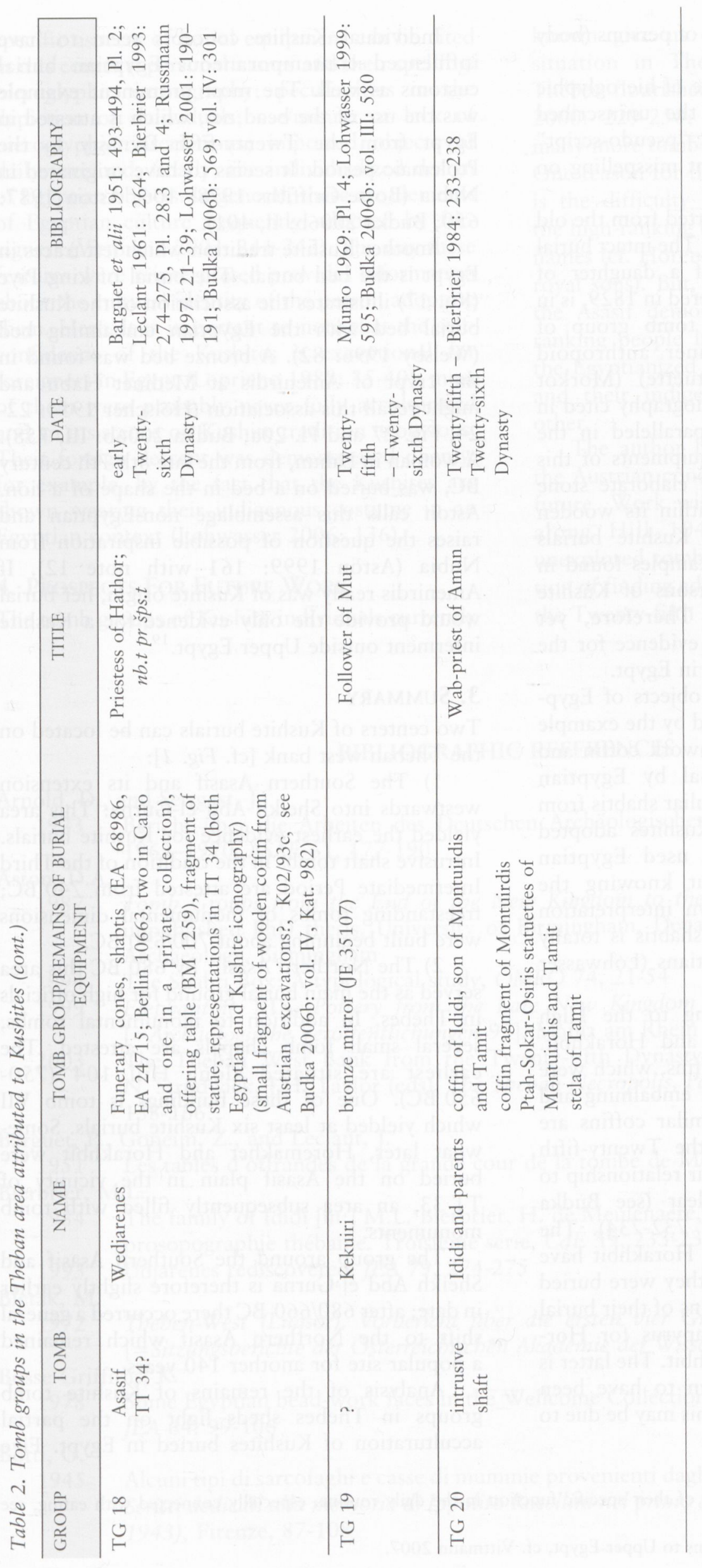


2) Peculiarities in depictions of persons (body proportions, coiffure, costume).

3) The use/misuse or absence of hieroglyphic inscriptions on objects (e.g., the uninscribed Osiris figure of Kherirw; the "pseudo-script" on coffin lid reg. $305 \mathrm{a}$; frequent misspelling on the various coffins, etc.).

4) Objects of daily use imported from the old homeland (cf. drinking vessel). ${ }^{18}$ The intact burial of Tjesraperet, a wet nurse of a daughter of Taharqa, which Rosellini discovered in 1829 , is in some respects similar to the tomb group of Kherirw (arsw-coffin, two inner anthropoid coffins, Ptah-Sokar-Osiris statuette) (Morkot 2000: 250 and 291 and the bibliography cited in Table 2). Some objects are unparalleled in the standard repertoire of burial equipments of this period. This holds true for the elaborate stone vessels and a bronze mirror within its wooden box. Mirrors are common in Kushite burials (Lohwasser 2001: 98). Some examples found in Egypt can be attributed to persons of Kushite origin (cf. TG 19, Kekuiri). Therefore, yet another feature can be cited as evidence for the partial acculturation of Kushites in Egypt.

5) Individualized design of objects of Egyptian origin. This is best illustrated by the example of the burial of Niw. Her openwork coffin and her shabtis are highly unusual by Egyptian standards. Furthermore, the peculiar shabtis from TT 99 demonstrate that the Kushites adopted Egyptian burial customs and used Egyptian equipment, sometimes without knowing the function or inventing their own interpretation for it. The Kushite concept of shabtis is totally different from that of the Egyptians (Lohwasser 2001: 99-103).

Very unusual coffins belong to the High Priests of Amun Horemakhet and Horakhbit. These are so-called ancillary coffins, which were filled with refuse material from embalming and then deposited near TT 33. Similar coffins are attested for Egyptians during the Twenty-fifth and Twenty-sixth Dynasties; their relationship to the actual burial remains unclear (see Budka 2006a: 99; Budka 2006b, III, 732-734). The burial places of Horemaket and Horakhbit have yet to be found, but proof that they were buried in Egypt comes from some remains of their burial equipment, like an amuletic papyrus for Horemakhet and canopics for Horakhbit. The latter is the only Kushite who is known to have been supplied with canopic jars, and this may be due to his links with the royal family.
Individual Kushite concepts seem to have influenced contemporaneous Egyptian burial customs as well. The most prominent example was the use of the bead net, which is attested in Egypt from the Twenty-fifth Dynasty to the Ptolemaic period. It seems to have originated in Nubia (Bosse-Griffiths 1978: 106; Aston 1987: 650; Budka 2006b: II, 401).

Another Kushite tradition which left traces in Egypt is the bed burial. The burial of king Piye (Ku. 17) illustrates the association of the Kushite burial bed with the Egyptian embalming bed (Welsby 1996: 82). A bronze bed was found in the crypt of Amenirdis at Medinet Habu and might recall this association (Hölscher 1954: 2224, Fig. 27 and Pl. 20a; Budka 2006b: III, 758). A woman in Lahun, from the late 8 th-7th century $\mathrm{BC}$, was buried on a bed in the shape of a lion. Aston calls this assemblage non-Egyptian and raises the question of possible inspiration from Nubia (Aston 1999: 161 with note 12). If Amenirdis really was of Kushite origin, her burial would provide the only evidence for a Kushite interment outside Upper Egypt. ${ }^{19}$

\section{Summary}

Two centers of Kushite burials can be located on the Theban west bank [cf. Fig. 1]:

1) The Southern Asasif and its extension westwards into Sheikh Abd el-Gurna: This area yielded the earliest evidence for Kushite burials. Intrusive shaft tombs in the tradition of the Third Intermediate Period are attested from $740 \mathrm{BC}$; freestanding tombs of monumental dimensions were built beginning about 700/690 BC.

2) The Northern Asasif: By 680 BC this area served as the main burial ground for high officials in Thebes. In addition to monumental tombs, several small tomb chapels are attested. The earliest are situated along Hill 104 (750$650 \mathrm{BC}$ ). One of these buildings is tomb VII which yielded at least six Kushite burials. Somewhat later, Horemakhet and Horakhbit were buried on the Asasif plain in the vicinity of TT 33, an area subsequently filled with tomb monuments.

The group around the Southern Asasif and Sheikh Abd el-Gurna is therefore slightly earlier in date; after $680 / 660 \mathrm{BC}$ there occurred a general shift to the Northern Asasif which remained a popular site for another 140 years.

Analysis of the remains of Kushite tomb groups in Thebes sheds light on the partial acculturation of Kushites buried in Egypt. Five

${ }^{18}$ For the use of such vessels because of their specific function in the daily routine, especially connected with eating, see Seidlmayer 2002: 103.

${ }^{19}$ For the restriction of Kushite remains to Upper Egypt, cf. Vittmann 2007. 
specific aspects of burial equipment can be cited in this context: personal names and their spelling/ hieroglyphic orthography; peculiarities in the depiction of individuals; use/misuse or lack of hieroglyphic inscriptions; imported objects of daily use; and, finally, the individualized design of Egyptian objects. In general, these are elements of Egyptian culture frequently adopted by foreigners (Vittmann 2003: 241-242). The way these features were reinterpreted provides information about the cultural identity of the person adopting them. Here, it is important to note that the selfconfidence of the Kushites is exceptional for foreigners in Egypt (Loprieno 1988: 35-40): most of them were probably never fully acculturated and an insistence on Kushite tradition is obvious. Their foreign descent was demonstrated openly, for example, by the fact that the Kushites are shown wearing their indigenous costume in an Egyptian context (Lohwasser 2006: 136).

\section{Prospects For Future Work}

The tomb groups of Kushite individuals currently known give us only a glimpse of the actual situation in Thebes during the Late Period. Thebes flourished under Kushite rule (Morkot 2000: 229-250; Redford 2004: 115-117) and many more tombs and burials are to be expected. One reason for the apparent scarcity of evidence is the difficulty of identifying Kushites among the high-ranking officials who may bear Egyptian names (cf. Horemakhet and Horakhbit and other royal sons). But, as the example of tomb VII in the Asasif demonstrates, the burials of lowerranking people like Irw and Kherirw testify to the Egyptianized status of Kushites on one hand and their indigenous cultural identity on the other.

The author hopes to resume excavations in the Austrian concession in the Asasif in the near future. Work will focus on the small buildings along Hill 104, especially on the as yet unexplored tomb west of tomb VII, in anticipation of finding additional evidence for Kushites of the Twenty-fifth and Twenty-sixth Dynasties.

\section{BIBLIOGRAPHIC REFERENCES}

Arnold, D., and Settgast, J.

1973 Bericht über die Arbeiten des Deutschen Archäologischen Instituts Kairo in Qurna von 1963-1970, ASAE 61, 177-190

Aston, D.A.

1987 Tomb Groups from the End of the New Kingdom to the Beginning of the Saite Period, unpublished PhD thesis, University of Birmingham, Department of Ancient History and Archaeology, Birmingham

1994 The Shabti Box: A typological study, OMRO 74, 21-54

1999 Elephantine XIX. Pottery from the Late New Kingdom to the Early Ptolemaic Period [=Archäologische Veröffentlichungen 95], Mainz am Rhein

2003 The Theban West Bank from the Twenty-fifth Dynasty to the Ptolemaic Period [in:] N. Strudwick, J.H. Taylor (eds), The Theban Necropolis, Past, Present and Future, London, 138-166

Barguet, P., Goneim, Z., and Leclant, J.

1951 Les tables d'offrandes de la grande cour de la tombe de Montouemhat, ASAE 51, 491-508 Bierbrier, M.L.

1984 The family of Ididi [in:] M.L. Bierbrier, H. de Meulenaere, S. Snape, J.H. Taylor, Notes de prosopographie thébaine. Troisième série, CdÉ 59, 233-238

1993 Udjarenes rediscovered, JEA 79, 274-275

Bietak, M.

1972 Theben-West (Luqsor). Vorbericht über die ersten vier Grabungskampagnen (1969-1971) [=Sitzungsberichte der Österreichischen Akademie der Wissenschaften 278/4], Wien

Bosse-Griffiths, K.

1978 Some Egyptian bead-work faces in the Wellcome Collection at University College, Swansea, JEA 64, 99-106

Botti, G.

1945 Alcuni tipi di sarcofaghi e casse di mummie provenienti dagli scavi fiorentini di el Hibeh [in:]

Scritti dedicati alla memoria di Ippolito Rosellini nel primo centenario della morte (4 Giugnu 1943), Firenze, 87-108 
Bresciani, E.

1972 L'expédition franco-toscane en Égypte et en Nubie (1828-1829) et les antiquités égyptiennes d'Italie, BSFE 64, 5-29

Budka, J.

2003 Ptah-Sokar-Osiris-Statuetten aus Grab VII im Asasif [in:] M. Hasitzka, J. Diethart, G. Dembski (eds), Das Alte Ägypten und seine Nachbarn, Festschrift zum 65. Geburtstag von Helmut Satzinger, Österreichisches Literaturforum, Krems, 32-42

2006a Deponierungen von Balsamierungsdepots im spätzeitlichen Theben. Befund, Kontext und Versuch einer Deutung [in:] H. Roeder, J. Mylonopoulos (eds), Archäologie und Ritual. Auf der Suche nach der rituellen Handlung in den antiken Kulturen Ägyptens und Griechenlands, Wien, 85-103

2006b Die Spätzeit in Theben-West: Das Asasif. Bestattungsbrauchtum und Friedhofsstruktur anhand der Ergebnisse der österreichischen Ausgrabungen in den Jahren 1969-1977, unpublished $\mathrm{PhD}$ thesis, University of Vienna, Wien

2007 Tomb VII in the Asasif: Its owners, date and implications [in:] J.-Cl. Goyon, Ch. Cardin (eds), Proceedings of the Ninth International Congress for Egyptologists in Grenoble [=Orientalia Lovaniensia Analecta 150], Leuven-Paris-Dudley, Mass., 241-250

in press Bestattungsbrauchtum und Friedhofsstruktur im Asasif. Eine Untersuchung der spätzeitlichen Befunde anhand der Ergebnisse der österreichischen Ausgrabungen in den Jahren 1969-1977 [=Untersuchungen der Zweigstelle Kairo], Wien [2010]

Budka, J., Kammerzell, F.

2007 Kuschiten in Theben: Eine archäologische Spurensuche, Der Antike Sudan 18, 163-177

Dunham, D.

1950 The Royal Cemeteries of Kush, I. El-Kurru, Cambridge, Mass.

1955 The Royal Cemeteries of Kush, II. Nuri, Boston

Eigner, D.

1984 Die monumentalen Grabbauten der Spätzeit in der Thebanischen Nekropole [=Denkschriften der Österreichischen Akademie der Wissenschaften 8, Untersuchungen der Zweigstelle Kairo 6], Wien

El-Sayed, R.

1999 A la recherché des statues inédites de la cachette de Karnak au Museé du Caire (I), ASAE 74, $137-158$

Fakhry, A.

1943 The Tomb of Paser (no. 367 at Thebes), ASAE 43, 389-438

Firenze

1982 The Archaeological Museum of Florence (catalogue, no author)

Graefe, E.

1990 Das Grab des Ibi, Obervermögenverwalters der Gottesgemablin des Amun (Thebanisches

Grab Nr. 36), Publication du Comité des Fouilles Belges en Egypte, Brussels

2003 Das Grab des Padihoressnet, Obervermögensverwalter der Gottesgemahlin des Amun (Thebanisches Grab Nr. 196) [=Monumenta Aegyptiaca IX], Tournhout

Gras, C.

1985 Des pharaons aux premiers chrétiens: Musée des Beaux-Arts de Dijon, 7 déc. 1985-10 mars 1986, Dijon

Hölscher, U.

1954 The Excavations of Medinet Habu V. Post-Ramesside Remains [=Oriental Institute Publications 66], Chicago

Kitchen, K.A.

1996 The Third Intermediate Period in Egypt (1100-650 BC), Warminster

Klasens, A.

1975 An amuletic papyrus of the 25th dynasty, OMRO 56, 20-28

Laurent, V.

1997 Antiquités égyptiennes. Inventaire des collections du Musée des Beaux-Arts de Dijon, Dijon

Leahy, A.

1994 Kushite monuments at Abydos [in:] Ch. Eyre, A. Leahy, L.M. Leahy (eds), The Unbroken

Reed. Studies in the Culture and Heritage of Ancient Egypt in Honour of A.F. Shore $[=$ Egypt Exploration Society, Occasional Publications 11], London, 171-192 
Leclant, J.

1961 Montouemhat, quatrième prophète d'Amon, Prince de la ville [=Institut français d'archéologie orientale, Bibliothèque d'étude 35], Le Caire

1965 Recherches sur les monuments thébains de la XXVe Dynastie dite éthiopienne [=Institut français d'archéologie orientale, Bibliothèque d'étude 36], Le Caire

Lohwasser, A.

1999 Die Darstellung der Tracht der Kuschitinnen der 25. Dynastie [in:] S. Wenig (ed.), Studien zum antiken Sudan. Akten der 7. Internationalen Tagung für meroitistische Forschungen vom 14. bis 19. September 1992 in Gosen/bei Berlin [=Meroitica 15], Wiesbaden, 586-603

2001 Die königlichen Franen im antiken Reich von Kusch, 25. Dynastie bis zur Zeit Nastasen [=Meroitica 19], Wiesbaden

2006 Fremde Heimat. Selektive Akkulturation in Kusch [in:] E. Czerny, I. Hein, H. Hunger, D. Melman, A. Schwab (eds), Timelines. Studies in Honour of Manfred Bietak [=Orientalia Lovaniensia Analecta 149/3], Leuven-Paris-Dudley, Mass., 133-138

Loprieno, A.

1988 Topos und Mimesis. Zum Ausländer in der ägyptischen Literatur [= Ägyptologische Abhandlungen 48], Wiesbaden

Morkot, R.G.

2000 The Black Pharaos, Egypt's Nubian Rulers, London

Munro, P.

1969 Eine Gruppe spätägyptischer Bronzespiegel, ZÄS 95, 92-109

Parkinson, R.B.

1999 Cracking Codes. The Rosetta Stone and Decipherment, London

Payraudeau, F.

2003 La designation du gouverneur de Thèbes, RdÉ 54, 131-153

Perdu, O.

1994 Un canope de Nesptah, fils aîne de Montouemhat [in:] C. Berger et alii (eds), Hommages à Jean Leclant, vol. 4 [=Institut français d'archéologie orientale, Bibliothèque d'étude 106/4], 273-276

Priese, K.-H.

1968 Nichtägyptische Namen und Wörter in den ägyptischen Inschriften der Könige von Kusch, MIO 14, 165-191

Redford, D. B.

2004 From Slave to Pharao. The Black Experience of Egypt, Baltimore-London

Schneider, H. D.

1977 Shabtis. An Introduction to the History of Ancient Egyptian Funerary Statuettes with a Catalogue of the Collection of the Shabtis in the National Museum of Antiquities at Leiden, vol. I, Leiden

Seeber, C.

1976 Untersuchungen zur Darstellung des Totengerichtes im alten Ägypten [=Münchner Ägyptologische Studien 35], München

Seidlmayer, St. J.

2002 Nubier im ägyptischen Kontext im Alten und Mittleren Reich, Mitteilungen des SFB "Differenz und Integration" 2. Akkulturation und Selbstbehauptung, Orientwissenschaftliche Hefte 4/2002, Halle-Wittenberg, 89-113

Straßburg

1990 Pharaonen-Dämmerung. Wiedergeburt des Alten Ägypten (catalogue without author)

Strudwick, N.

1995 The Fourth Priest of Amun, Wedjahor, GM 148, 91-94

2000 The Theban Tomb of Senneferi [TT 99]. An overview of work undertaken from 1992 to 1999 [Pls LV-LVIII], Memnonia 11, 241-266

Taylor, J.H.

1985 The Development of Theban Coffins during the Third Intermediate Period, unpublished PhD thesis, University of Birmingham 1985 
2003 Theban coffins from the Twenty-second to the Twenty-sixth Dynasty: dating and synthesis of development [in:] N. Strudwick, J.H. Taylor (eds), The Theban Necropolis, Past, Present and Future, London, 95-121

Vittmann, G.

2003 Ägypten und die Fremden im ersten vorchristlichen Jahrtausend [=Kulturgeschichte der antiken Welt 97], Mainz am Rhein

2007 A question of names, titles, and iconography. Kushites in priestly, administrative and other positions from Dynasties 25 to 26, Der Antike Sudan 18, 139-161

Welsby, D.A.

1996 The Kingdom of Kush. The Napatan and Meroitic Empires, London

Wenig, St.

1990 Pabatma - Pekereslo - Pekar-tror, Ein Beitrag zur Frühgeschichte der Kuschiten [in:] Studia in honorem Fritz Hintze [= Meroitica 12], 333-352

Zibelius-Chen, K.

2009 Zur Lesung eines Personennamens der 25. Dynastie, GM 221, 105-107 